\title{
Effect of Different Seasons on Taggar Goat Performance
}

\author{
I, Bushara ${ }^{1}$., ElGazafey Besheer ${ }^{2}$., M.O.Mudalal ${ }^{1}$., D M Mekki ${ }^{\text {. , }}$ \\ Umsalama A. M.Ahmed $^{3}$, A M A Abu Nikhaila ${ }^{4}$ \\ ${ }^{1}$ Department of Animal Production, Faculty of Natural Res. \& Environmental Studies, \\ University of Kordofan \\ ${ }^{2}$ Faculty of Medicine, University of ELdaein, Sudan. \\ ${ }^{3}$ Dept. of Biology, Faculty of Art and Sciences, Taif University, Saudi Arabia . \\ ${ }^{4}$ Department of Dairy Production, Faculty of Animal Production, University of Khartoum, \\ Shambat, Sudan
}

\begin{abstract}
Effect of climate change through season of birth was carried out to evaluate some reproductive and productive performance of mountain goat (Taggar goats). Forty seven (47) mature Taggar goats were used in this experiment. Animals were allocated in two groups according to season of birth, rainy season and dry season. The results indicated that rainy season kidders secured higher litter size 1.45 compared with dry season kidders 1.18. Where kidding rate was high in rainy season kidders 100\% compared with dry season kidders. Body weight was heavier at kidding and weaning time for rainy season kidders compared with dry season kidders. The kidding interval and service period for the rainy season kidders shorter compared with dry season kidders. In conclusion the season of birth was sharply affected goat reproductive and productive performance.
\end{abstract}

Keywords: Dry land, nuba mountain, climate, season, range land, taggar.

\section{INTRODUCTION}

Climate change, particularly global warming, may strongly affect production performance of farm animals worldwide. Climate change affects natural resources (such as water sources, land and pastures), biodiversity and livestock health (Thornton, 2010). Under tropical environmental conditions, the main factor influencing the productivity of goat's flocks is climatic seasonality. Since raising goats under extensive conditions implies that environmental factors and their interactions (relief and altitude, climate parameters and climate change) are of central importance and they determine the levels of performance and productivity (Nassif and El Amiri, 2011). This change rise as a seasonal fluctuation in feed resources, poor management and diseases, especially endoparasitism. The impact of climate change on pastures and rangelands may include deterioration of pasture quality towards poorer quality (Field, 2005). The widespread of negative impacts on forage quality affect livestock productivity (Porter et al., 2014).

The indirect effects of climate driven changes in animal performance result mainly from alterations in the nutritional environment. However changes in climate would affect the quality and quantity of forage produced (Topp and Doyle, 1996a). Livestock nutrition is the major constraint to sustainable livestock production in drylands especially during the dry seasons (Mnene et al 2004). In the Arid and Semi-Arid Lands, rainfall is the key driving factor and is characterized by high diversity and failure that lead to frequent droughts. A drought is a prolonged dry season, two to three or more dry seasons.

The level of reproductive performance is dependent on the interaction of genetic and environmental factors, but this performance is particularly susceptible to the latter, for example, the seasonal availability of nutrients can affect reproduction considerably. Season of parturition influence the duration of postpartum anoestrus (Rojero et al, 2005), kidding interval (Majele-Sibanda et al, 2000). Goat populations in Sudan were estimated to be 42 million, the mainly composed of Nubian, Desert, Nilotic and Mountain (Taggar) breeds. Under the tropical condition of western Sudan, the traditional farming system is practiced on communal grazing areas (Ahmed et al 2001). Goats fulfill their nutrition needs mainly by eating the available vegetation. They rarely receive any supplements. The supply of nutrients from the veld fluctuates between years and seasons. When basic requirements are 
not fulfilled goats start to use body weight loss, this might be reflected on goat's productivity performance (Ramirez-Perez et al 2000). The goal of this study is to explore the effects of season change on Taggar goat's productivity under dry land conditions of western Sudan.

\section{MATERiAl AND MethodS}

\subsection{Study Area}

This study were conducted in Dalanj area (longitudes $12.02^{\circ} \mathrm{N}$, Latitudes $29.39^{\circ} \mathrm{E}$ ) Southern Kordofan state. The mean monthly temperature ranged from $25.8 \mathrm{C}^{\circ}$ in July to $31.3 \mathrm{C}^{\circ}$ in April. The mean maximum is about $39 \mathrm{C}^{\circ}$ in the three months prior the rainy season with peak temperature in May. The mean minimum Temperature varied between $17 \mathrm{C}^{\circ}$ in January to more than $20 \mathrm{C}^{\circ}$ at the onset of the rains in May. Annual rainfall of a range 500-800 mm, with peak rain in August. The relative humidity of $35 \%$ rose to $75 \%$ during the rainy season.

\subsection{Experimental Animals}

Forty seven pregnant Taggar does ranging in age between 1-4 years, with three bucks were acquired by direct purchase local market. Does and bucks were treated with the necessary medication against endo-and ecto-parasites (AGVET, USA $1.0 \mathrm{ml} / 50 \mathrm{~kg}$ body weight subcutaneously Ivomec super drench) and vaccinated against goat pox, Anthrax and Hemorrhagic Septicemia. The does were ear tagged, weighted and divided into two groups according to season of birth (rainy season and dry seasons) as group 1 and 2 consisting of 29 and 18 does respectively. Mix all animals were allowed free grazing on an early pasture from 8.00 am to $6.00 \mathrm{pm}$. The does were weighed at weekly interval for 8 weeks before kidding and 12 weeks post kidding.The does were fasted overnight before being weighed.

\subsection{Statistical Analysis}

The data statistically analyzed according to complete randomizes design using Statistical Package for the Social Sciences, software package (SPSS version 10 1996). Analysis of covariance was carried out. Duncan's Multiple Range Tests (DMRT) was also used to test means significance differences.

\section{RESUlts}

\subsection{Effect of Season on Litter Size and Kidding Rate}

The effect of season of birth on litter size is displayed in (Table 1). The results showed the rainy season kidder had secured large litter size compared with the dry season kidders. The two seasons of birth exert significantly $(\mathrm{P}<0.05)$ effect on the kidding rates were $100 \%$ for the rainy and $94.4 \%$ dry season respectively.

Table1. Effect of season on litter size and kidding rate

\begin{tabular}{|l|l|l|l|l|l|}
\hline Season of birth & N & No. of kidding doe & No. of kids & Litter size & Kidding rate \% \\
\hline Rainy season & 29 & 29 & 42 & $1.45 \pm 0.09^{\mathrm{a}}$ & 100 \\
\hline Dry season & 18 & 17 & 20 & $1.18 \pm 0.09^{\mathrm{b}}$ & 94.4 \\
\hline
\end{tabular}

\subsection{Effect of Season on Body Weight at Kidding, and Weaning}

The does that kidded during the rainy season maintained a significantly $(\mathrm{P}<0.05)$ heavier body weight than those which kidded in the dry season. The season of birth secured insignificant $(\mathrm{P}>0.05)$ effect on weight at weaning, however, the does kidded during the rainy had heavier body weight at weaning than does kidding during the dry seasons (Table 2).

Table 2. Effect of season on the body weight at kidding and weaning

\begin{tabular}{|l|l|l|l|l|l|}
\hline $\begin{array}{l}\text { Season of } \\
\text { birth }\end{array}$ & $\mathbf{N}$ & Body weight at kidding & $\begin{array}{l}\text { Body weight at } \\
\text { weaning }\end{array}$ & $\begin{array}{l}\text { Body weight } \\
\text { change }\end{array}$ & $\begin{array}{l}\text { change } \\
\text { \% }\end{array}$ \\
\hline Rainy season & 29 & $25.08 \pm 0.28^{\mathrm{a}}$ & $22.01 \pm 0.29$ & $-3.07 \pm 0.21^{\mathrm{b}}$ & 12.2 \\
\hline Dry season & 17 & $24.15 \pm 0.23^{\mathrm{b}}$ & $21.21 \pm 0.35$ & $-2.94 \pm 0.30^{\mathrm{a}}$ & 12.2 \\
\hline
\end{tabular}




\subsection{Kidding Interval and Service Period}

Season of birth exerted in significant effect on kidding interval and service period despite that the rainy season kidders have shorter kidding interval and service period compared with dry season kidders (Table 3).

Table 3. Effect of season on kidding interval and service period (days)

\begin{tabular}{|l|l|l|l|}
\hline Season of birth & $\mathbf{N}$ & Kidding interval & Service period \\
\hline Rainy season & 27 & $257.77 \pm 3.32$ & $80.98 \pm 4.81$ \\
\hline Dry season & 17 & $261.93 \pm 7.95$ & $83.25 \pm 3.44$ \\
\hline${ }^{\text {abcd }}$ Values in same column with different superscripts differ at $P<0.05$ \\
\hline
\end{tabular}

\section{DISCUSSION}

The season of birth significantly $(\mathrm{P}<0.01)$ affected litter size, does that kidding during the rainy season maintained litter size of 1.45 compared to 1.18 kids for the cool dry season kidders. This result complies with several authors, Silva et al (1998), Madibela et al (2002) and Dadi et al (2008). The large litter size during the rainy season could be due to the availability of green folder grasses and forages which resulted in higher body condition score and body weight at mating and may be also due to high temperature accruing during dry season which delay feed intake for the dry season kidders which agree with Field (2005) and Marai et al (2008)and Porter et al (2014) who reported that the heat-induced loss of appetite can also delay the time an animal takes to reach market weight by a year or more. This claim was confirmed by Amoah et al (1996) who reported that improved mating weights of the dams significantly improved litter size.

The effect of season on reproductive performance of the goats has been reviewed by Suleiman et al (1990) and EL-Hage (1992) indicated that seasonal effects results from seasonal availability of quality grazing. In the present experiment the high percentages of the kidding rate recorded during the rainy season, may be due to availability of good grazing during the rainy season, and this reflected that natural grazing supplied enough nutrients to meet the requirements for conception and kidding, another possible explanation may be due to the presence of the male in the flock running with the female all time, this result confirms by Silva et al (1998) and Webb and Mamabolo (2004).

The effects of season of birth on goat post partum body weight was highly significant, this could be attributed to the changing nutritional status of the animals with the seasonal availability of green grasses, this result in agreement with EL-Hag (1992) who reported that the nutritive value of rangeland grasses decline sharply during the dry season. The high body weight at kidding obtained in the rainy season may be due to availability of feed in rainy season; however the does that kidded in the dry season had conceived in the late rainy season and faced the long pregnancy period with decline of the nutritive value in grazing pasture during the dry season, with high temperature and heat distress which reduce the rate of animal feed intake and result in poor growth performance (Rowlinson, 2008), which reflected the decline in their body weight during the kidding and weaning time.

In present experiment the high losses in live weight during of the cool dry season kidders may reflect the seasonal changes, this result agree with the findings of Majele-Sibanda et al (2000) and Junior et al (2001) who reported that ewes lost 13.6 to $15.6 \%$ of their live weight during the dry season. Season of birth did not affect significantly service period and kidding interval, the despite longer kidding interval was notice in the dry season. This complies with Mtenga et al (1994) and Alexandre et al (2000). The differences in kidding interval may be related to availability of feed from pasture during the rainy and dry seasons, which have direct influence on ovulation rate and fertility, since the nutritional stress appears to be a prime probable cause of cyclicity and long kidding interval in the goats, body weight changes support this hypothesis.

\section{REFERENCES}

[1] Ahmed MMM, El Hag FM, Wahab FS and Salih SF (2001) Feeding strategies during dry summer for lactating desert goats in a rainfed area under tropical conditions. Journal of Small Ruminant Research., 39:161-166.

[2] Alexandre G, Aumont G, Fleury J and Arquet R (2000) Reproductive performance of Creole goats of Guadeloupe. In: Proceedings of the $7^{\text {th }}$ International conference on goat, 15-21 May2000, France P.1039. 
[3] Amoah EA, Gelaye S, Guthrie P and Jr Rexroad C E (1996) Breeding season and aspect of reproductive of female goat. Journal Animal Science, 74:723-728.

[4] Dadi H, Duguma G, Shelima B, Fayera T, Tadesse M, Woldu T and Tucho TA (2008) Nongenetic factors influencing post-weaning growth and reproductive performances of Arsi-Bale goats. Livestock Research for Rural Development: 20 (7).

[5] El-Hag FM (1992) Effects of chopping and wilting on tropical grassland silage quality in south Kordofan, Sudan. Journal of African Livestock Reseach,1: 11-14.

[6] Field CR (2005) Where there is no Development Agency. A manual for pastoralists and their promoters. NR International, Aylesford, Kent, UK. 260 pp.

[7] Madibela OR, Mosimanyana BM, Boitumelo W S and Pelaelo TD (2002) Effect of supplementation on reproduction of wet season kidding Tswana goats. South African Journal of Animal Science, 32:14-22.

[8] Majele - Sibanda L , Bryant M J and Ndlovu LR (2000) Live weight and body condition changes of Matebele does during their breeding cycle in a semi-arid environment. Small Ruminant Research, 35(3):271-275.

[9] Maraia IFM , El- Darawany AA, Fadiel A and Abdel-Hafez MAM (2008) Reproductive performance traits as affected by heat stress and its alleviation in sheep. Tropical and Subtropical Agroecosystems, 8: 209 - 234.

[10] Mnene WN, Muthiani EN, Ndung'u J N, Manyeki JK and Ndathi AJN (2004) Assessment of possible activities for increased resilience of agro-pastoral and pastoral communities to crises in southern Kenya. Kenya Agricultural Research Institute (KARI)/ ASARECA Animal Agricultural Research Network (A-AARNet) Report.

[11] Mtenga LA , Kifaro GC and Belay Berhanu (1994) Studies on factors affecting reproductive performance and mortality rates of Small East African goats and their crosses. In: Small ruminant Research and Development in Africa, Proc.2nd Biennial Conference of the African Ruminant Research Network. ILRA, AICC, 7-11 Dec, 1992, Arusha, Tanzania. P.69-74.

[12] Nassif F, and Amiri BEl (2011) Promoting multidisciplinary research to improve goat production systems in Morocco . Economic, social and environmental sustainability in sheep and goat production systems, Options Méditerranéennes, A no. 100: 299-303.

[13] Ramirez-Perez A H , Buntinx SE , Tapia-Rodriguez $\mathbf{C}$ and Rosiles $\mathbf{R}$ (2000) Effect of breed and age on the voluntary intake and the micromineral status of non pregnant sheep. 1. Estimation of voluntary intake. Small Ruminant Research, 36:49-55.

[14] Rojero RDM, Lagunas AAM, Santamaria LR and Mendez JV (2005) Reproductive performance in three goat breeds under dry tropics conditions in Guerrero, Mexico Veterinary Mexicain, 36(2):147-155.

[15] Rowlinson P (2008) Adapting Livestock Production Systems to Climate Change - Temperate Zones. Livestock and Global Change conference proceeding. May 2008, Tunisia.

[16] Silva E, Galina MA, Palma JM and Valencia J (1998) Reproductive performance of Alpine dairy goats in a semi-arid environment of Mexico under a continuous breeding system. Journal of Small Ruminant Research, 27: 79-84.

[17] SPSS (1996) Statistical Packages for the Social Sciences. Cary, North Carolina

[18] Sulieman AH, Sayers AR and Wilson RT (1990) Evaluation of Shugor, Dubasi and Watish subtypes of Sudan Desert sheep at El-Huda National sheep Research Station, Gezira Province, Sudan. International Livestock Centre fr Africa (ILCA) Research Report No. 18. ILCA, Addis Ababa, Ethiopia. 30pp.

[19] Thornton, PK (2010) Livestock Production: Recent Trends, Future Prospects. CGIAR/ESSP Program on Climate Change, Agriculture and Food Security (CCAFS), International Livestock Research Institute (ILRS) 365, 2853-2867.

[20] Topp, CFE, Doyle CJ (1996a) Simulating the impacts of global warming on milk and forage production in Scotland. 1. The effects on dry matter yield of grass and grass-white clover stands. Agricultural Systems 52, 213-242.

[21] Porter JR, Xie L, Challinor AJ, Cochrane K, Howden SM, Iqbal MM, Lobell DB, Travasso MI (2014) Food security and food production systems. In: Climate Change 2014: Impacts, 
Adaptation, and Vulnerability. Part A: Global and Sectoral Aspects. Contribution of Working Group II to the Fifth Assessment Report of the Intergovernmental Panel on Climate Change [Field CB, Barros VR, Dokken DJ and 13 others (eds.)]. Cambridge University Press, Cambridge, United Kingdom and New York, NY, US A, pp. 485-533.

[22] Webb E C and Mamabolo M J (2004) Production and Reproduction characteristic of South African indigenous goats in communal farming system. Journal of Animal Science, 34 (1): 236239. 